\title{
Title of the website: Socialism Goes Global
}

URL: http://socialismgoesglobal.exeter.ac.uk/

Bogdan C. lacob

\section{OpenEdition}

\section{Journals}

Electronic version

URL: http://journals.openedition.org/rccs/8864

DOI: $10.4000 /$ rccs.8864

ISSN: 2182-7435

\section{Publisher}

Centro de Estudos Sociais da Universidade de Coimbra

\section{Printed version}

Date of publication: 1 May 2019

Number of pages: 211-212

ISSN: 0254-1106

\section{Electronic reference}

Bogdan C. lacob, «Title of the website: Socialism Goes Global ", Revista Crítica de Ciências Sociais [Online], 118 | 2019, Online since 26 April 2019, connection on 25 September 2020. URL : http:// journals.openedition.org/rccs/8864; DOI : https://doi.org/10.4000/rccs.8864 


\section{Espaço Virtual}

\section{Title of the website: Socialism Goes Global URL: http://socialismgoesglobal.exeter.ac.uk/}

Socialism Goes Global is the virtual platform of the major international project "Socialism Goes Global: Cold War Connections between the 'Second' and 'Third Worlds" (hereafter SGG), funded by the Arts and Humanities Research Council (in the United Kingdom), with support from the University of Exeter. SGG addresses both how socialist states in Europe crafted a global role for themselves in the post-war period, and how these international engagements reshaped socialist politics, societies and cultures "back home". In doing so, it seeks to provide new insights into the circulation of ideas during the Cold War and to explore "the socialist world" as a dynamic hub of global interactions during the second half of the twentieth century.

The project comprises seven academic institutions: the Universities of Belgrade, Columbia, Exeter, Leipzig, Oxford, the Hungarian Academy of Sciences, and the University College London. The website provides details about this scholarly consortium, its funding, and individuals engaged in the section "About" and "Research Team". The latter contains brief biographies of each researcher involved in the project with a focus on their specific research interests. Such emphasis allows the visitor to acquire a clear image of the topics, themes, and areas of study favoured by the 12 participating academics. This way, outside scholars can identify subject clusters examined by members of the SGG team, which opens the possibility for establishing networks that connect a broader community beyond the immediate membership of the project.

Visitors can follow SGG's activities on the website in three ways. First, on the "Home" section there is a Twitter feed that permanently provides information on events, publications, conferences, and presentations initiated by the SGG team as well as other similar announcements (including job opportunities) pertinent to the themes of the project (e.g., Eastern Europe in global context, socialist states and decolonization, history of international organizations, trans-regional circulations, etc.). Second, the website contains the domain "Our Conferences", where information is offered on events organized between 2014 and 2019 such as "Africa, Eastern Europe and the Dream of International Socialism", "Socialist Internationalism: Histories and Afterlives", "Alternative Global Geographies", or "Alternative Encounters: The 'Second World' and the 'Global South', 1945-1991". Third, there is the section "Opportunities", which is split in two: "Jobs and Studentships" and "Calls for Papers" (CFP). The former comprises notifications about posts offered by the academic institutions within SGG or its external partners such as KADOC Documentation and Research Center on Religion and Society in Leuven, the Institute of European Studies of the Jagiellonian University in Krakow, or the Imre Kertész Kolleg in Jena. The latter subfield contains announcements about upcoming events organized by SGG - the most recent one is the CFP for the 
workshop "Historicizing 'Whiteness' in Eastern Europe and Russia", which is planned to occur in Bucharest (June 25-26, 2019) and is organized by the Universities of Exeter, Hull, Warsaw, and Bucharest. An interactive facet of the website is its "Blog", a platform for either team members or external researchers to discuss issues and events directly relevant to the SGG agenda. For instance, there is information on a series of on-going seminars on "Socialisms and Postsocialisms in a Global Context", organized by Professor Paul Betts, at the University of Oxford. The "Blog" presents information on the team's published work or about public interventions such as the interview with Professor James Mark (University of Exeter), on BBC Radio 4. There are also brief texts on various topics such as "The Sixties and Red Africa", the first black arts festival in Dakar (1966) as well as several reviews to volumes relevant for the themes of SGG.

The website perseveres in mapping wider tendencies within the field of the global history on the "Second World" through the section "Other Conferences". It introduces academic gatherings that discuss issues pertaining to globalization, decolonization, international organizations' dynamics, expertise circulations across regions and continents, or counterhegemonic, non-Western, international projects during and after the Cold War. Generally speaking, the aim of the SGG website is to inform researchers about topics, initiatives, or publications that decentre established narratives about the twentieth century by turning the scholar's and the general public attention toward alternative alignments and global encounters.

Bogdan C. Iacob

\section{Bogdan C. Iacob}

Associate Researcher, Department of History, University of Exeter Amory Building, Rennes Drive, Exeter, EX4 4RJ, United Kingdom Contact: cristianiacob.bogdan@googlemail.com ORCID: https://orcid.org/0000-0003-0735-6272 